Article

\title{
Muslim and Buddhist Youths in Switzerland: Individualising Religion and Striving for Recognition?
}

\author{
Martin Baumann * and Rebekka Christine Khaliefi \\ Department for the Study of Religions, University of Lucerne, 6002 Lucerne, Switzerland; \\ E-Mails: martin.baumann@unilu.ch (M. B.), rebekka.khaliefi@unilu.ch (R. C. K.) \\ * Corresponding author
}

Submitted: 29 March 2020 | Accepted: 30 April 2020 | Published: 20 August 2020

\begin{abstract}
Since the second half of the 20th century, immigrants and refugees from numerous countries have arrived in Switzerland. With their long-term settlement, the immigrant minorities have established cultural and religious associations to maintain their cultural and religious traditions and to teach their children the faith and religious practices from the country of origin. In contrast to the first immigrant generation, the second generation has had concurrent social influences from the Swiss ordinary school system and the cultural-religious traditions of their parents. This article asks to what extent the young generations have continued the religious traditions brought by their parents and what changes have occurred in adapting religious practices, ideas and collective forms to the new socio-cultural environment. In addition, we study whether and how the second generations have striven to move away from the often-marginalised social position of their parents and engage with social recognition in Swiss society. To provide answers to these pertinent questions, the article will draw on the examples of first and second-generation Muslims and Buddhists in Switzerland and refer to the theoretical model designed by the American scholars Fred Kniss and Paul Numrich. The article argues that not only outward changes of religiosity are observable among second-generation youths, but also that despite an intensified degree of individualisation, some of their newly founded youth associations strive for civic participation and social recognition in the public arena of Swiss civil society.
\end{abstract}

\section{Keywords}

authority; Buddhists; civic engagement; individualisation; Muslims; second generation; social recognition; Switzerland; youth groups

\section{Issue}

This article is part of the issue "Religious Minorities and Struggle for Recognition" edited by Christophe Monnot (University of Lausanne, Switzerland/University of Strasbourg, France) and Solange Lefebvre (University of Montreal, Canada).

(C) 2020 by the authors; licensee Cogitatio (Lisbon, Portugal). This article is licensed under a Creative Commons Attribution 4.0 International License (CC BY).

\section{Introduction: Second-Generation Immigrant Youths in European Diversity}

In the second half of the 20th century, European countries faced large-scale arrivals of immigrant workers, spouses, and refugees. Over time, they established places of assembly and founded associations to maintain their religious and cultural traditions and to teach their children the faith and religious practices from the country of origin. The immigrants' children were socialised both in the European countries and in the cultural-religious traditions of their parents' country of origin. The basic question both of the parent generations and of many academic studies has been to what extent the young generations continue the religious traditions brought by the parents and what changes have occurred in adapting religious practices and ideas to the new socio-cultural environment. Numerous studies argue that there has been a shift towards the individualisation of religiosity and an emphasis on religious concepts 
over practices among Muslim, Hindu, Buddhist and Sikh youth (Herding, 2013; Limacher, Mattes, \& Novak, 2019; Sedgwick, 2015).

This article aims to provide a theory-led comparative analysis of changes of religiosity from the first to the second generation in two exemplary religious minorities, i.e., Muslims and Buddhists in Switzerland. Additionally, we will examine to what extent these generally individualised young people and the religious youth associations that are sometimes established strive for civic engagement and social recognition in public arenas of Swiss society. We define the second generation as the descendants of immigrants who have been socialised in Switzerland, whilst the first generation immigrated to Switzerland as adults.

In theory, we apply the analytical approach by Kniss and Numrich (2007) differentiating religious associations concerning preferences of religious authority and engagement with civic participation. Civic engagement activities, we will argue, can also encompass actions to make one's voice heard with the aim of claiming respect and social recognition for the minority and faith. The topic of recognition admittedly covers an enormous field of discussion and reflection (van den Brink \& Owen, 2007). It covers analytical approaches, such as those carried out by Honneth (1995), accentuating the ideal of the autonomy of moral subjects, Taylor (1994), examining politics of recognition in multicultural societies, and Fraser $(2003,2018)$, calling for a 'politics' of recognition with a politics of redistribution.

The article will first introduce the theoretical perspective, followed by the two case studies of Muslims, the majority with Kosovo-Albanian and Bosnian background, and Vietnamese Buddhists in Switzerland. We employ the theoretical perspective to map generational dynamics and the civic engagement of individuals and religious associations. We selected these two minorities as Muslims and Islam constitute the most publicly discussed and stigmatised religious minority in Switzerland (Ettinger, 2018) while Buddhism is positively referenced in public discourse (Kollmar-Paulenz \& Funk, 2010). Moreover, while Albanian-speaking and Bosnian Muslims are considered as badly integrated, Vietnamese enjoy good social recognition due to a positive stereotyping, as well as being integrated and successful (Beglinger, 2017). Following this, we discuss the appropriateness of employing the moral-order map, assess reasons for the degree of striving for social recognition and provide explanations for the patterns of change. A brief conclusion will highlight the main findings.

The main thesis of the article states that the generational transmission of religious practices and ideas in Switzerland leads to decisive shifts of individually interpreted religiosity, dependent on specific contextual factors. Young Muslims position themselves socially to correct the bad image of Islam. Hence, independent Muslim youth groups strive for social recognition in public arenas of civil society. In contrast, young Buddhists growing up with a positive image of their religion engage in civil society more individually and informally.

\section{Analytical Perspective: Moral Order Map}

Studying civic engagement and one of its sub-forms, the claim for respect and recognition, poses the difficulty of a lack of a widely accepted definition and an agreement on core items. For example, Keeter, Zukin, Andolina, and Jenkins (2002) chose 19 core activities which ranged from "voting, to volunteering, to signing petitions" (Keeter et al., 2002, p. 1). Alternatively, Wray-Lake, Metzger, and Syvertsen (2016) listed "behaviours, values, knowledge, and skills that comprise political and prosocial contributions to community and society" as characteristics of civic engagement (Wray-Lake et al., 2016, p. 4). The authors recognised the highly multifaceted nature of civic engagement, which includes actions such as voting, volunteering, activism, and environmental conservation. In contrast to the abundance of quantitative studies, qualitative studies on religion and civic engagement are comparatively rare. The study by Todd and Rufa (2013) represents one of the few exceptions as they conducted 15 in-depth interviews to examine the extent to which Christian congregations in the US-Midwest promote social justice. Also, Kniss and Numrich (2007) proposed a heuristic 'moral order map' to locate the degrees of civic engagement of immigrant religious communities in the greater Chicago area. The map ranges from no civic engagement to various forms of engagement in the arenas of civil society, the government, and the economy. The authors defined civic engagement as "the public action of individuals and groups as they interact with and participate in the organisations, associations, and institutions of society" (Kniss \& Numrich, 2007, p. 10). We have identified this qualitative approach as being particularly suitable for the analytical aims of the article as it enables the comparative study of religious individuals and groups and takes into consideration religious rationales for civic engagement and different authority structures of groups. The approach rests on three dimensions of differentiation, i.e., on the degree of sectarianism, on the locus and emphasis of the moral authority of the religious group, and on the most central moral project of the group (Kniss \& Numrich, 2007, p. 9).

The 'degree of sectarianism' of a religious community is decisive insofar as sects commonly emphasise specific religious interpretations and practices and break with long-established interpretations. In protest against established tradition, the sectarian view claims to offer the authentic interpretation of the founder's message, relaying it into the correct words and a true way of life (Kniss \& Numrich, 2007, pp. 21-34). This dimension often strongly affects the other two dimensions.

Secondly, the authors position a religious community's 'locus of moral authority' on a spectrum between the poles of an individual and a collective moral authority (Kniss \& Numrich, 2007, pp. 38-40). The individual as the 
prime place of moral authority bases his/her decisions and values on personal reasons and experiences. In contrast, the collective locus of moral authority is based on an understanding that "the authority to define ultimate values is grounded in the collective religious tradition" (Kniss \& Numrich, 2007, p. 40). Believers are expected to follow the instructions of the ecclesiastical and/or scriptural authority.

Thirdly, the dimension of a religious community's 'moral project' also ranges between the poles of groups with a tendency towards collectivist moral projects and those with a tendency towards individualist moral projects (Kniss \& Numrich, 2007, p. 55-65). The content and communal form of a moral project at the individualist end of the continuum "[seek] the maximisation of individual utility" (Kniss \& Numrich, 2007, p. 56) and the moral improvement and/or moral self-perfection of the individual. The opposite side of the continuum, the collectivity as a moral project, favours the collective good and aims at "establishing a just and righteous social order rather than reforming individuals" (Kniss \& Numrich, 2007, p. 56). Collectivist moral projects may result in joint civic actions with public criticism of unjust social structures and the aim of amending social problems. In the US, Kniss and Numrich point to Roman Catholic and Muslim immigrant communities as prime examples of this expression with their civic engagement for poor and marginalised people (Kniss \& Numrich, 2007, pp. 60-63).

Our case studies illustrate these different types of civic engagement. Using the approach by Kniss and Numrich (see Figure 1), we indicate the shift between the first and second generation. While the Muslim and Buddhist first generations tend towards the collectivity as a locus of authority, the authority locus of the second generations shifts towards the individual with a trend towards a societal moral project.

\section{Analysing Immigrant Religious Minorities and Generational Dynamics}

We will use the model to analyse the range of the first and second generation. While Kniss and Numrich focused solely on immigrant religious communities, we have also included the people of the first and second generation to examine generational changes based on the model.

Overall, we suggest that the civic participation of immigrant communities leaning towards the poles of the societal moral project will also encompass activities claiming respect and social recognition in society. In conceptual terms, Fraser suggested "to treat recognition as a question of social status," (Fraser, 2018, p. 89, emphasis in original) terming it status model. She contrasts her status model with the so-called standard identity model which, following Taylor and Honneth, claims respect and recognition for specific groups and their cultural identity (Fraser, 2018, p. 88-89). Fraser held this identity model as "deeply problematic" as the model would reify culture and "impose a single, drastically simplified group identity, which denies the complexity of people's lives" (Fraser, 2018, p. 89). The status model, however, would analyse the social status of group members in the per-

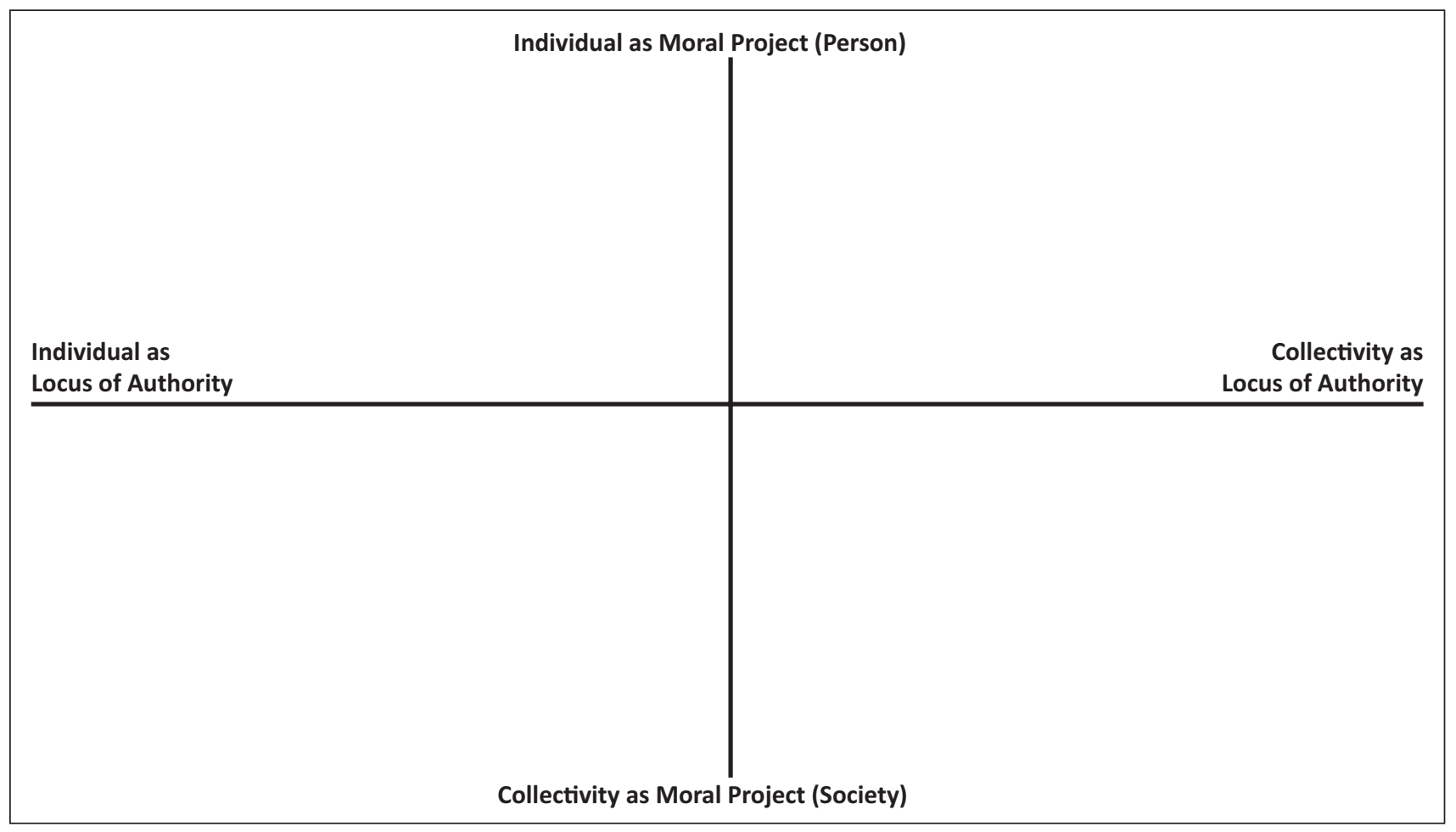

Figure 1. Model by Kniss and Numrich (2007). 
spective of justice as "some individuals and groups are denied the status of full partners in social interaction simply as a consequence of institutionalised patterns of [less or minor] cultural value" ascribed to them (Fraser, 2018, p. 91). In this regard, Fraser opted for a conception of justice and norm of "parity of participation" (Fraser, 2018, p. 94) which criticises forms of misrecognition as "it denies some individuals and groups the possibility of participating on a par with others in social interaction" (Fraser, 2018, p. 92).

While scholars in practical philosophy and sociology have paid little attention to religion and religious groups in discussing claims for recognition, Fraser explicitly included issues of minority religious practices and controversies (Fraser, 2018, pp. 99-101). She demonstrated that her proposed status model relying on the norms of participatory parity and justice provide a standard for evaluating "the effects of institutionalised patterns of cultural value on the relative standing of minorities vis-à-vis majorities" (Fraser, 2018, p. 100, emphasis in original). In this regard, claimants demanding cultural or religious recognition were to show "that the institutionalisation of majority cultural norms denies them participatory parity" as well as to show "that the practices whose recognition they seek do not themselves deny participatory parity" neither to various group members nor to nonmembers (Fraser, 2018, p. 100). While applying Fraser's status model, we need to analyse whether members or groups of the discussed religious minorities are denied any parity of participation.

\subsection{Muslims in Switzerland}

In Switzerland, the first Muslims arrived due to recruiting schemes from Turkey in the 1960s and 1970s, followed by considerable numbers of Muslims fleeing the disintegrating state of Yugoslavia in the 1990s. In 2019, the heterogenic Muslim minority of some 458,000 people were composed of $37 \%$ from the Balkans, $11.5 \%$ from Turkey, Muslims from various African and Asian countries, and $35 \%$ Swiss Muslims. The latter comprises large parts of naturalised former Kosovo-Albanians, Bosnians and Turks. Nine out of ten Muslims adhere to Sunni traditions (Monnot, 2013; Tunger-Zanetti \& Schneuwly-Purdie, 2019).

In Switzerland, according to the 2014 survey completed by the Federal Office of Statistics (2016), only a small percentage of first-generation Muslims practise their religion by visiting the mosque and praying daily. The percentage of Muslims who visit the mosque weekly was stated as $12 \%$ and those praying more or less daily as almost 30\% (Federal Office of Statistics, 2016, pp. 9, 12). Overall, Gianni, Giugni, and Michel (2015) put the percentage of religiously observant Muslims at 10 to $15 \%$ (Gianni et al., 2015, pp. 86-90). In contrast, the vast majority of less to non-religious Muslims rarely perform the five prayers a day and only occasionally visit the mosque.
Political scientist Matteo Gianni emphasised the variety of individual ways in which the Islamic faith and prescriptions were lived among the silent majority of Muslims in the early 2000s (Gianni, 2005, pp. 6-7). Meanwhile, these varieties have grown since then. Translating Gianni's findings to the moral order map, the individual as the locus of authority is characteristic of many Muslims in Switzerland. Observant religious Muslims tend more towards the collectivity as represented by the mosque and a knowledgeable imam (Gianni, 2005, p. 24-25). The content of the moral project seems to be more individualised among the less and non-religious Muslims, while it tends more towards collectivity with the religious Muslims. This is expressed in activities such as volunteer work and giving donations. The graphical representation on the map reproduces the wide range of understandings and attitudes of firstgeneration Muslims as a strung-out ellipse. The various mosques, as places with numerous social, cultural and religious services, tend towards civic engagement on the community level, and those with an employed imam lean towards the collectivity as the locus of authority (Gianni et al., 2015, pp. 63-79; Martens, 2013).

The generation of young Muslims aged 15 to 30 constitutes approximately 120,000 people in Switzerland. The survey by Käppler and Morgenthaler (2013) on religiosity among young Christians, Muslims, Hindus and Jews aged 13 to 17 showed, despite its limitation to Swiss-German conurbation areas, that a minority percentage of the surveyed young Muslims are either nonreligious (16.4\%) or highly religious (11.5\%). A strong majority of $72 \%$ can be labelled as somewhat or selectively religious (Zehnder Grob, 2013, p. 64).

Furthermore, the large-scale qualitative study by Baumann, Endres, Martens, and Tunger-Zanetti (2017) on young Muslims aged 15 to 30 provided in-depth views of religious attitudes and practices of young Muslims. The researchers employed varied approaches to contact young male and female Muslims, visiting youth centres, contacting key persons at mosques, directly addressing young Muslims, and establishing contacts via the Facebook site 'Imra Cy' and the project's university website. The sample strove for a large spectrum of young Muslims concerning gender, age, education, religious profile and country of origin of the parents.

Overall, the researchers conducted 61 narrative individual interviews, 28 with young Muslim women and 33 with young Muslim men (Baumann et al., 2017, pp. 7-9). The analysis of the multifarious data which comprised more than 5,000 minutes audio recording evidenced a cognisant and reflexive approach towards Islamic ideas and a decrease of religious practices among the interviewed young Muslims (Baumann et al., 2017, pp. 11, $15,29)$. In contrast to their parents, young Muslims, a large proportion of them Albanian-speaking and Bosnian Muslims, attempt to understand Islamic ideas and norms in their terms, suitable for their situation in Switzerland. They distance themselves from the religious-cultural 
practices of their parents (Baumann et al., 2017, p. 13) and take a comparative and scrutinising stance towards the Islamic norms and guidelines of the various Islamic authorities (Tunger-Zanetti, Martens, \& Endres, 2019, p. 195). For example, as Yalçuk (male, 26 years) explains concerning the observation of Islamic commandments: "I simply need a good explanation. It must make sense to me" (Baumann et al., 2017, p. 28, translation by the authors). Statements such as this indicate that the varied spectrum of understanding and practising Islam is tending towards the pole of the individual as the locus of authority on the map.

In addition, due to the decisive critical discourse about Islam and Muslims in Switzerland, almost all young Muslims report negative experiences of discrimination, exclusion and rejection (Baumann et al., 2017, p. 31). Young female and male Muslims developed different strategies to handle the pejorative Islam discourse. While some retreat to the private domain with their religious practices and others adapt these selectively at work, a third group emphasises their Muslim belonging and claims the right to practice in public. This group openly criticises the negative image of Islam and demands rights and claims social recognition by public actions. In the words of Fraser, this group of young Muslims speaking out criticises "being denied the status of a full partner in social interaction and prevented from participating as a peer in social life as a consequence of institutionalised patterns of cultural value that constitute one as comparatively unworthy of respect or esteem" (Fraser, 2018, p. 92). The negative image of Islam and Muslims repro- duced by the media and conservative politicians constitutes a "status subordination" which denies the "norm of participatory parity" (Fraser, 2018, p. 92). In contrast to their parents who tend to remain in a marginalised societal position, often in the private realm and some in the mosque, determined young Albanian-speaking and Bosnian Muslims engage and participate in the public arena of Swiss civil society and call for respect and recognition. Hence, applied to the graphical representation on the map, young Muslims lean more than their parents towards the pole of the individual as the locus of authority and more towards the pole of the collectivity as a moral project (see Figure 2).

Turning to Muslim youth organisations, the explorative study by Endres, Tunger-Zanetti, Behloul, and Baumann (2013) employed qualitative methods of visiting internal and public religious and leisure events organised by these organisations, conducting participant observations and semi-structured interviews and observed web-based activities of Muslim youth groups on their websites and social media platforms (Endres et al., 2013, pp. 26-27; Tunger-Zanetti \& Endres, 2019, p. 127). The study provided evidence that only a minority of young Muslims had been affiliated to a youth group in 2012 . Among the approximately 100 youth groups, the majority were closely connected to a mosque, usually headed by an imam and continuing the same patterns of nationallinguistic bonding (Tunger-Zanetti \& Endres, 2019, p. 134). However, the close organisational linkage brought forth critical voices like that of 25-year-old Gezim:

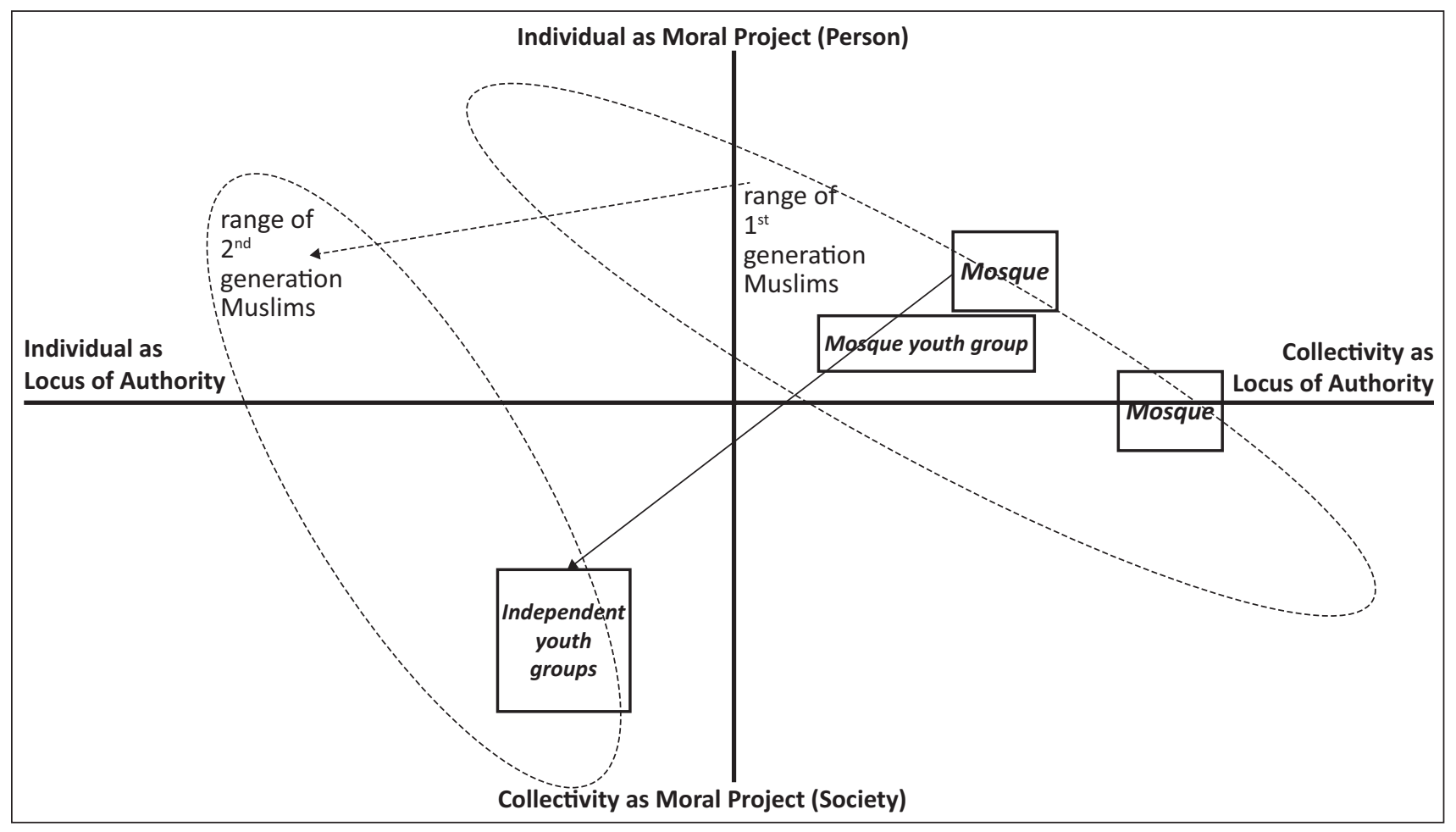

Figure 2. Locating first and second-generation Muslims on the moral order map. 
There is no common language between Swiss Muslim youngsters and the imams. On the one hand, there is a generation gap, on the other, the imams commonly do not speak and teach in Swiss German, but in Turkish, Albanian, etc....The imams do not match the language of the youths and often do not know the situation in which the youths live in Switzerland. (Endres et al., 2013, p. 66, translation by the authors)

This frustration and the will to engage beyond their ethnic group has led young Muslims to set up independent youth groups, traversing established infrastructures of mosque associations and linguistic, national, and cultural boundaries. In these groups, apart from organising various leisure and sports activities in an Islamic setting, young Muslims are eager to teach themselves an observant Muslim life with an understanding of Islamic scripts, ideas and values. Importantly, young Muslim men and women stress a conscious self-understanding of being 'Swiss Muslims' rather than merely tolerated "Muslims in Switzerland" (Tunger-Zanetti \& Endres, 2019, p. 135). As 18-year-old Bosnian Ismeta explains:

I would love to see something that serves the whole Swiss community. So people would notice that Muslims belong to Switzerland and are not only THERE. That they not only exist but that we are a part of society. I would also wish that they get more politically active. (personal interview 179, research material 2015, translation by the authors)

Such volunteer activities seek, among other things, to help gradually change and develop the public image of Muslims and Islam. In addition, groups such as the Association of Islamic Youth Switzerland challenge the pejorative public discourse and occasionally organise public activities such as information booths, participate in Christian-Muslim dialogue and at times gather for demonstrations to disseminate their ideas about Islam and the Muslim way of life (Tunger-Zanetti \& Endres, 2019 , p. 136). With all due caution in turning these findings into a graphical representation on the map, independent Muslim youth groups strongly lean towards the pole of the collectivity as a moral project and collective actions in the political realm. Figure 2 translates the findings to the map.

The heuristic figure displays the strong shift of second-generation youths towards the individual as the locus of authority. Due to the pejorative societal discourse about Islam and Muslims, more young Muslims appear to be socially engaged and aim to change the stigmatising picture. The range of attitudes remains wide, however.

\subsection{Buddhists in Switzerland}

We analysed shifts between the first and second generation of Vietnamese Buddhists by using data from a qualitative research project carried out from 2016 to 2020. In the study, the authors studied the religiosity of young Vietnamese Buddhists in Switzerland and Germany. We conducted narrative interviews with 22 young Vietnamese Buddhist adults between 17 and 30 years of age at the time of the study. The sample included persons who were involved in the pagodas and people with little to no relation to the pagodas. We gained the interview partners by using recommendations, key persons from pagodas and Buddhist youth organisations as well as social media and youth-specific events in Switzerland and Germany. Method-wise, the authors proceeded ethnographically and used participating observations in the pagodas. In this article, we draw upon data from Switzerland.

In 2018, about 15,000 Vietnamese lived in Switzerland. The majority came between 1975 and 1995 because of the Vietnam War (Weigelt, 2013, p. 107). The German-speaking part of Switzerland, in particular, provided Vietnamese contingent refugees with a new home away from home during this period.

Vietnamese immigrants are an ethnically and religiously heterogeneous community in Switzerland. Informed estimates assume some $50 \%$ of the Vietnamese people are part of Mahayana Buddhism. In 2020, three pagodas existed in Switzerland, with two pagodas near Berne and Lucerne in the Swiss-German region and the third pagoda near Lausanne in the French-speaking region. In the pagodas, Vietnamese Buddhists practice a mixture of Chan and Pure Land Buddhism. The monks and nuns emphasise the recitation of sutras and the acquisition of religious merit. About $80-90 \%$ of the practising Buddhists in pagodas are female and older than 40 years (Baumann, Eulberg, \& Weigelt, 2011, p. 17). Young adults, however, are strongly underrepresented. Fieldwork impressions gained by the authors suggest that the average age is shifting even higher. Affiliated associations of lay Buddhists (Buddhist youth association) support two of the pagodas. In these Vietnamese Buddhist youth groups, the lay Buddhists practice Buddhism and continue elements of Vietnamese culture and tradition.

The majority of Vietnamese Buddhists are likely to belong to the spectrum within the category of the selectively religiously oriented. Likewise, a minority of first-generation Vietnamese Buddhists do not attend a pagoda at all and practice only in the private domestic sphere, representing the category of religiously distanced.

Therefore, on the moral order map, we can show a wide range of religious understanding among the first generation, tending towards the pole of the individual as a moral project. In addition, as most Vietnamese of the immigrant generation highly respect the Buddhist monks and nuns as guides for individual and collective religiousness (cf. Baumann, 2000, pp. 61-67), a majority tends towards the collectivity as the locus of authority. Collective social and civic engagement beyond their community only rarely occurs. We noticed small differ- 
ences between the alignments of the three pagodas. The two pagodas near Lucerne and Lausanne, for example, present themselves as open to the Swiss majority society. The pagoda in Berne, on the other hand, is primarily aimed at its community.

The spectrum of second-generation religiosity ranges from non-religious to a small minority of religious people. The majority of respondents can be categorised as selectively religious. They only visit the pagodas during festivals but not for regular chanting and services at the weekend. Transferred to the moral order map, the positioning of religious authority strongly shifts towards the pole of the individual as the locus of authority.

The minority of young Buddhists involved in the Buddhist youth associations is rather irregular and selfdetermined. On the moral order map, the second generation is shown as tending towards both the pole of the individual as a moral project and the pole of the collectivity as a moral project.

Since young Vietnamese Buddhists are less represented in pagodas, they practice Buddhism more as a way of life. They are involved in associations of the majority society, in the neighbourhood or the inter-religious area. This form of religiosity is directed at the individual and civic engagement in the informal sphere. What is striking is that they distance themselves strongly from the parent generation. They often refer to the religiosity of their parents' generation and demand a stronger separation between Vietnamese culture and Buddhism. As 25-year-old Nathalie emphasises:

Tradition and religion go hand in hand and that sometimes bothers me because I already have the Swiss in me, or I am already quite Swiss. And this has always bothered me, the conservative elements, which is why I decided to get to the bottom of it for myself by searching for literature myself. (personal interview, translation by the authors)

Second-generation Buddhists choose religious authorities by themselves but do not accord them authority by dint of their position. In this regard, the majority of young Buddhists tackle religion independently and based on their own choices. Quite a few align with the Western image of Buddhism and the Buddhism represented by the Vietnamese Zen Master Thich Nhat Hanh. The 22-yearold female Buddhist Kim describes this examination of her religiosity:

A line [of Buddhist interpretation] that I like is just that of Thich Nhat Hanh.... like it more because it is more related to everyday life and to mindfulness. I also feel that it brings me something in everyday life. I also notice how it is practical, everyday life and what is said. This is only my personal opinion, but when I joined Mahayana Buddhism, it simply didn't make sense for me. (personal interview, translation by the authors)
The quote highlights the attitude of young Buddhist adults towards their religion and questions the religious practice of their parents' generation. It also indicates a turn towards a Western understanding of Buddhism as expressed by Zen Master Thich Nhat Hanh.

Unlike Muslims, young Vietnamese have experienced less discrimination due to their religious affiliation. Discrimination, or the attribution of foreignness, occurs more because of their ethnic roots and appearance. Young Vietnamese react with different strategies. As a rule, over-adaptation to the Swiss majority society is evident. In addition, success in education is of great importance (cf. Baumann et al., 2011, p. 14). They do not seek social recognition through official groups in the same way that Muslims do, but through informal engagement and adaptation. Their civil society involvement is manifested in the informal sphere and as part of Buddhism which is seen as a way of life. 21-year-old Mai Linh emphasises:

If you practice meditation or pray, or always go to temples, sure it's good, it certainly helps you, but I find that all of this...you find it in the smallest action, e.g., you bring in your neighbour's newspaper every day.... think it starts at the very beginning and if you can't be a good person in everyday life or treat other people in a way that you would treat people in the temple, then you can't be a good Buddhist. (personal interview, translation by the authors)

Like the female Buddhist Mai Linh, the majority of respondents understand civic engagement as part of their 'Buddhist being.' Here, however, a shift towards the pole of the individual as the locus of authority is striking as the Vietnamese youth only irregularly attend collective religious services and gatherings (see Figure 3 ). Compared to the parent generation, the members of the second generation are stronger volunteers in Swiss civil society and less within the Vietnamese Buddhist pagodas. Unlike Muslims, however, they are not involved in the political or formal sphere. They are involved in informal activities.

In conclusion, it seems justified to say that young Buddhists seek social recognition through established structures. Referring to Fraser's status model, we observed that Buddhists in our case study achieve participatory parity based on upward mobility. Religious organisations support this mobility in strengthening the social recognition of the individual and less the collective (Bankston \& Zhou, 1995; Le, 2020). The interviewees of our study are not much involved in religious organisations, as they perceive a lack of peers. Nevertheless, we assume that the pagodas and youth organisations influence the young adults' search for recognition. A clear majority has adapted structurally to Swiss majority society and is engaged in the informal sector of community activities to demonstrate their belonging. Figure 3 translates the findings to the map. 


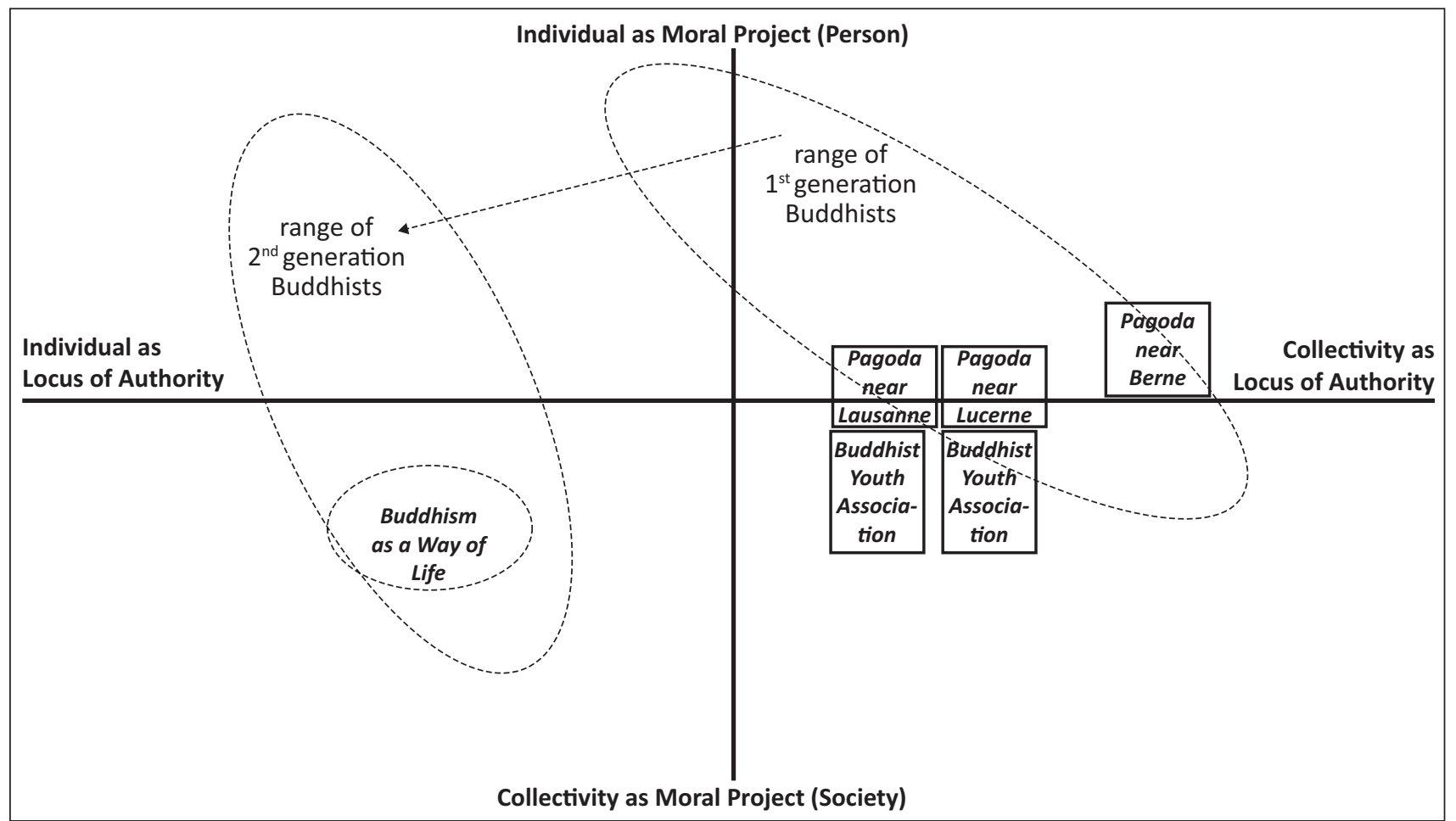

Figure 3. Locating first and second-generation Buddhists on the moral order map.

\section{Discussion and Explanation}

In this article, we use the moral order map and the approximate graphical location of first and second generations and their religious organisations to highlight generational dynamics. An advantage of this approach is that it demonstrates the wide range of religious selfunderstanding of both Muslim and Buddhist generations in Switzerland.

The used model is not without shortcomings, however. The actual location of a mosque, pagoda and youth group on the map can only be approximately set, and this is even more the case as regards locating the range of the first and second generations of the Muslim and Buddhist minorities. To some extent, the spectra can be only suggestive, as representative data on the different characteristics of the content of the moral project and the locus of authority are not widely available.

Nevertheless, the map provides an expedient frame to visually underscore the second generation's shift towards the pole of the individual practitioner as the locus of authority. The individualising shift of young Muslims and Buddhists socialised in Switzerland can be attributed to the overall trend of individualisation prevalent in Switzerland, Western Europe, North America and elsewhere. In recent decades, the dominant idea of religiosity as individual and private has developed, distanced from institutional religion and with almost unlimited options for the individual to select and define religious contents and practices (Stolz, Könemann, SchneuwlyPerduie, Engelberger, \& Krüggeler, 2014, pp. 181-186, 200-202). Our results of a shift towards individualisa- tion are mirrored by similar studies on young Muslims in other European countries (Herding, 2013; Jacobsen, 2009; Sedgwick, 2015; Voas \& Fleischmann, 2012), young Tamil Hindus in Germany (Marla-Küsters, 2015) and young Thai and Tibetan Buddhists in Great Britain and Switzerland (Schlieter, Kind, \& Lauer, 2014; Thanissaro, 2014). Also, for Canada, Ramji (2008) and Beyer and Ramji (2013), examining the religiosity of children from immigrant families, argued that young Muslims, Hindus and Buddhists considered themselves individually responsible for their religiousness. The intergenerational changes appear thus as a general trend in secondgeneration studies. Young adults negotiate their affiliation to religious institutions as part of their biography and their self-determined religiousness.

We assume that the reflexive and critical stance of young Muslims and Buddhists towards the religious practice of their parents' generation is strongly influenced by the Swiss school system. Children and adolescents are taught to ask for reasons and to think for themselves (Baumann et al., 2017, p. 28). Emphasis is placed by the school system on understanding and explanation. This socialisation towards reflexivity does not sit easily alongside rituals that young people often find boring and difficult to comprehend. Overall, there is a clear distancing from mosques and pagodas as places of religious authority.

Despite the overall trend of individualisation, a minority of young Muslims deliberately gather in youth groups. Notably, some young Muslims founded independent groups to transverse the national-linguistic patterns of mosque-affiliated youth groups. These indepen- 
dent groups do not only enable the young Muslims to self-responsibly organise religious, leisure and sports activities in an Islamic setting. They also serve to teach themselves an enhanced understanding of Islamic values, ideas and scripts and to jointly encourage living an observant Muslim life. While each young participant individually strives to deepen his and her Islamic comprehension reflexively, this endeavour is purposefully jointly done in a collective setting. Among these young Muslims, individualisation and distancing from the mosque does not necessarily include privatisation but the setting up of autonomous community structures to consciously support a self-empowerment and a challenging of the ascribed status subordination and misrecognition (Endres et al., 2013, pp. 63-75; Tunger-Zanetti \& Endres, 2019, pp. 135-141).

Furthermore, our findings demonstrate that independent Muslim youth groups and individual young Buddhists are more open to social engagement and participation in society than the established organisations founded by the first generations. In fact, engagement with social recognition among the first generations takes place within the mosque and pagoda, if at all, and is only occasionally voiced in the field of community activities. In contrast, engaged young Muslims-albeit limited in number-consciously campaign for their cause in the public arenas of politics and civil society. As distinct from these dedicated Muslims, young Buddhists commit themselves via the less outspoken informal engagement. They interpret Buddhism as a way of life, which finds ex- pression in actions such as respecting and helping neighbours and engaging in associations within Swiss society.

In particular, young Muslims increasingly collectively engage to achieve social recognition and a participatory parity. Young Muslims are confronted globally with the negative discourse of Islam (Bozorgmehr \& Kasinitz, 2018). Islam as an immigrant religion is generally more socially present than Buddhism, which is less regarded as an immigrant phenomenon. This stigmatisation and status subordination of Islam and Muslims corresponds to the positioning constraint that representatives of Islam in Europe express themselves more publicly than representatives of Buddhist institutions. The engagement of young Muslims and their claim for recognition is motivated by this discourse. As we have argued, young Muslims are keen to enhance the image of their religion. They work to counter the negative image by public actions in the communal and political arenas, calling for respect and social recognition of Muslims. They demand the same rights and an end to stigmatisation and social marginalisation. "We are also a part of Switzerland," declared a homemade poster held by a young Muslim demonstrator on the Day Against Islamophobia and Racism in 2011 in Bern (Figure 4).

In contrast, the engagement of young Buddhists appears to be more informal and less visible. In 2018, a young Buddhist woman put on an exhibition presenting her family history and her perspective on her Vietnamese roots having grown up in Switzerland. She intended to show how integration into a Vietnamese fam-

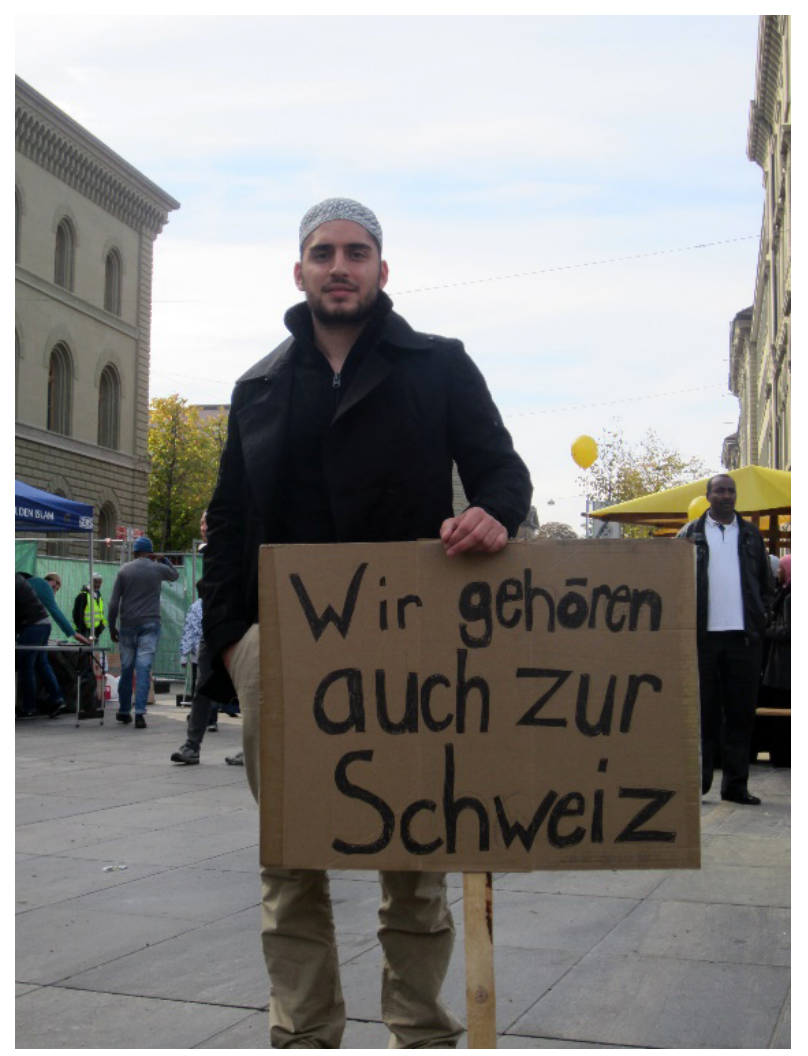

Figure 4. Young Muslim demonstrator on the Day Against Islamophobia and Racism (Endres et al., 2013, p. 52.). 


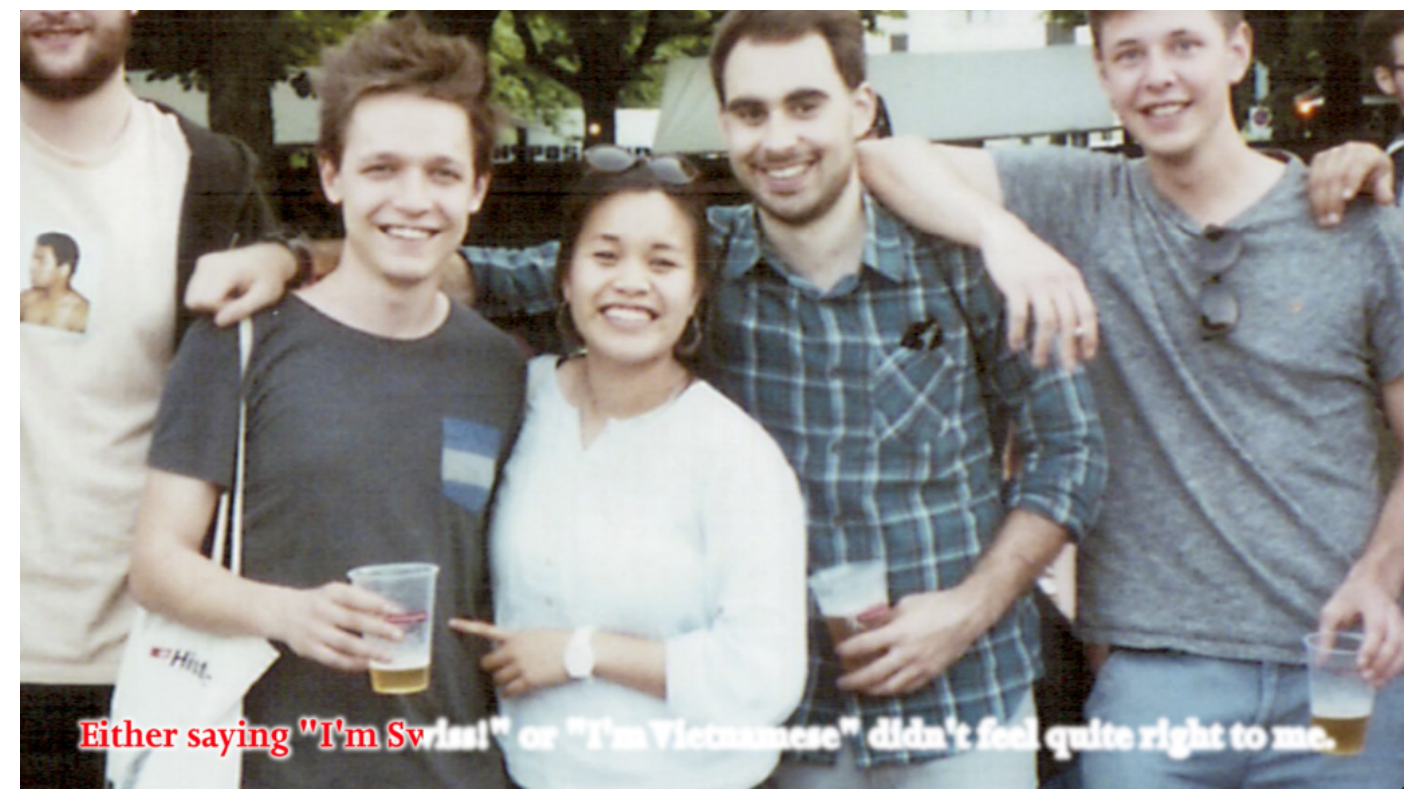

Figure 5. "Either saying 'I'm Swiss' or 'I'm Vietnamese' didn't feel quite right to me." Image from Hieu thao-With Love and Respect (2018), provided by Thi My Lien Nguyen.

ily and Swiss society can go hand in hand. In the private sphere, the family engages in Vietnamese culture, while in the public sphere the family has adapted to the conditions in Switzerland. While it is important for Muslims to influence the discourse, the young woman presents social participation at the micro-level with her exhibition. The young Buddhists may benefit from the fact that other Buddhist migrants like Tibetans have already established themselves in Switzerland (Schlieter et al., 2014). The positive discourse about Buddhism will certainly also be helpful to them.

Both cases demonstrate the stronger interest of both second generations to be more visible in Swiss society than the first generation. Notably, they highlight the importance of the impact made by the societal discourse of stigmatisation, in contrast to idealisation on the social engagement of young Muslims and Buddhists in different public arenas.

\section{Conclusion}

This article aimed to provide a theory-led comparison and analysis of the first and second generations of two immigrant minorities and how they interpret being religious. Furthermore, we intended to study the generational dynamics of how religion is perceived among second-generation youth. The model by Kniss and Numrich (2007) provided a convenient analytical framework within which to discern characteristics of the religious self-understanding of first and second generations and the religious organisations of these minorities. This comparison enabled us to highlight the range of how religion is personally interpreted and led to a graphical spectrum of understanding religion as more individualised or more collective.
The examples of Muslims and Buddhists illustrated the shifts of religious understanding among the immigrant generation towards a more individualised interpretation among the second generations. In addition, it became obvious that due to the negative discourse on Islam, young Muslims proved to be more civically and politically engaged in the public arena of civil society than the socially positively-perceived young Buddhists.

Apparently, the form and interpretation of being more or less religious among young Muslims and Buddhists are thus strongly aligned with dominant patterns of religiosity in Switzerland. These descendants of immigrants have overwhelmingly been structurally integrated into school, apprenticeships, and professions, and to a large extent assimilated into the dominant idea of religion and religiosity. Though the contents of their religious practices and ideas are different, the underlying grammar of religion as individual to a large extent has become similar.

Young Muslims draw inspiration for civic participation from Muslim intellectuals such as Mohamed Naved Johari, Islamic preachers and rap-musicians. For young Buddhists, on the other hand, the 14th Dalai Lama and the Zen Master Thich Nhat Hanh serve as role models for individual engagement in their local neighbourhood.

Despite these ideals and role models, only a minority of young people engage in youth activities and groups. Although they are often few, these second-generation people have realised it is down to them to uplift what is thus far a marginal social position as an immigrant and ethnic minority in a reluctantly welcoming Swiss society. While young Muslims get involved in organisations and politically claim their affiliation to Swiss society, young Buddhists get involved in the informal sector to demonstrate their affiliation with Swiss society. Social engage- 
ment such as volunteer services and participation in local initiatives such as inter-religious dialogue are useful means to make themselves visible and heard or to show that they belong to the Swiss society. Importantly, it also enables links with influential institutions in Swiss civil society, thereby strengthening their civic engagement in striving for social participation, respect and recognition.

\section{Acknowledgments}

We would like to express our thanks to Andreas TungerZanetti.

\section{Conflict of Interests}

The authors declare no conflict of interests.

\section{References}

Bankston, C. L., III, \& Zhou, M. (1995). Religious participation, ethnic identification, and adaptation of Vietnamese adolescents in an immigrant community. Sociological Quarterly, 36(3), 523-534.

Baumann, M. (2000). Migration, religion, integration: Buddhistische Vietnamesen und hinduistische Tamilen in Deutschland [Migration, religion, integration: Buddhist Vietnamese and Hindu Tamils in Germany]. Marburg: Diagonal.

Baumann, M., Endres, J., Martens, S., \& Tunger-Zanetti, A. (2017). 'Hallo, es geht um meine Religion!' Muslimische Jugendliche in der Schweiz auf der Suche nach ihrer Identität. ['Hello, it's about my religion!' Muslim youth in Switzerland in search of their identity]. Lucerne: Centre for Research on Religion. Retrieved from www.unilu.ch/fileadmin/fakultaeten/ ksf/institute/zrf/dok/Forschungsbericht_Hallo_es_ geht_um_meine_Religion.pdf

Baumann, M., Eulberg, R., \& Weigelt, F. A. (2011). Zugewanderte Religion, öffentlicher Raum und Wandel von Geschlechterrollen tamilischer Hindus und vietnamesischer Buddhisten in der Schweiz [Immigrant religion, public space and changing gender roles of Tamil Hindus and Vietnamese Buddhists in Switzerland] (Research Project NFP 58). Lucerne: University of Lucerne. Retrieved from http://www.snf.ch/ SiteCollectionDocuments/nfp/nfp58/NFP58_

Schlussbericht_Baumann.pdf

Beglinger, M. (2017, August 18). Warum sich Vietnamesen im Westen so gut zurechtfinden und als Integrationswunder gelten [Why Vietnamese find their way so well in the West and are considered a miracle of integration]. Neue Zürcher Zeitung. Retrieved from https://www.nzz.ch/gesellschaft/vietnamesenintegrationswunder-ld.1311265

Beyer, P., \& Ramji, R. (Eds.). (2013). Growing up Canadian. Muslims, Hindus, Buddhists. Montreal: McGillQueen's University Press.

Bozorgmehr, M., \& Kasinitz, P. (Eds.). (2018). Growing up Muslim in Europe and the United States. London: Routledge.

Endres, J., Tunger-Zanetti, A., Behloul, S. M., \& Baumann, M. (2013). Jung, muslimisch, schweizerisch. Muslimische Jugendgruppen, islamische Lebensführung und Schweizer Gesellschaft [Young, Muslim, Swiss. Muslim youth groups, Islamic lifestyle and Swiss society]. Lucerne: Center for Research on Religion, University of Lucerne.

Ettinger, P. (2018). Qualität der Berichterstattung über Muslime in der Schweiz [Quality of reporting on Muslims in Switzerland]. Bern: EKR.

Federal Office of Statistics. (2016). Religiöse und spirituelle Praktiken und Glaubensformen in der Schweiz. Erste Ergebnisse der Erhebung zur Sprache, Religion und Kultur 2014 [Religious and spiritual practices and forms of belief in Switzerland. First results of the 2014 survey on language, religion and culture]. Neuchâtel: Federal Office of Statistics.

Fraser, N. (2018). Recognition without ethics? In C. McKinnon \& D. Castiglione (Eds.), The culture of toleration in diverse societies. Reasonable tolerance ( $\mathrm{pp}$. 86-108). Manchester: University Press.

Fraser, N. (2003). Social justice in the age of identity politics: Redistribution, recognition, and participation. In N. Fraser \& A. Honneth (Eds.), Redistribution or recognition? A political-philosophical exchange (pp. 7-109). London: Verso.

Gianni, M. (2005). Muslime in der Schweiz. Identitätsprofile, Erwartungen und Einstellungen. Eine Studie der Forschungsgruppe "Islam in der Schweiz" (GRIS) [Muslims in Switzerland. Identity profiles, expectations and attitudes. A study by the research group "Islam in Switzerland"] (2nd ed.). Bern: BBL and the Swiss Commission for Migration. Retrieved from www.ekm.admin.ch/dam/data/ekm/ dokumentation/materialien/mat_muslime_d.pdf

Gianni, M., Giugni, M., \& Michel, N. (2015). Les Musulmans en Suisse. Profils et integration [Muslims in Switzerland. Profiles and integration]. Lausanne: PPUR.

Herding, M. (2013). Inventing the Muslim cool: Islamic youth culture in western Europe. Bielefeld: transcript.

Hieu thao-With Love and Respect. (2018). Camera Arts: Photography in the contexts of art, design, media and society. Camera Arts. Retrieved from https://cameraarts.ch/projects/hieu-thao-withlove-and-respect

Honneth, A. (1995). The struggle for recognition. Cambridge: Polity Press.

Jacobsen, C. M. (2009). Islamic traditions and Muslim youth in Norway. Leiden: Brill.

Käppler, C., \& Morgenthaler, C. (Eds.). (2013). Werteorientierung, Religiosität, Identitätsbildung und die psychische Gesundheit Jugendlicher [Value orientation, religiosity, identity building and the mental health of young people]. Stuttgart: Kohlhammer.

Keeter, S., Zukin, C., Andolina, M., \& Jenkins, K. (2002). 
The civic and political health of the nation: A generational portrait. Medford, MA: CIRCLE-The Center for Information \& Research on Civic Learning and Engagement. Retrieved from https://files.eric.ed.gov/ fulltext/ED498892.pdf

Kniss, F., \& Numrich, P. D. (2007). Sacred assemblies and civic engagement: How religion matters for America's newest immigrants. London and New Brunswick, NJ: Rutgers University Press.

Kollmar-Paulenz, K., \& Funk, E. (2010). Die Rezeption des tibetischen Buddhismus in öffentlichen Institutionen der Schweiz [The reception of Tibetan Buddhism in public institutions in Switzerland] (Final Report NFP 58). Bern: Institute for the Science of Religion and Central Asian Studies, University of Bern. Retrieved from www.relwi.unibe.ch/e40353/ e227976/e344644/e344650/Schlussbericht_ Rezeption_ger.pdf

Le, A. N. (2020). Upward or downward? The importance of organizational forms and embedded peer groups for the second generation. Ethnicities, 20(1), 136-154. https://doi.org/10.1177\% 2F1468796818796058

Limacher, K., Mattes, A., \& Novak, C. (Eds.). (2019). Prayer, pop and politics. Researching religious youth in migration society. Vienna: Vienna University Press.

Marla-Küsters, S. (2015). Diaspora-Religiosität im Generationenverlauf [Diaspora religiousness across generations]. Würzburg: Ergon.

Martens, S. (2013). Muslimische Wohltätigkeit in der Schweiz [Muslim charity in Switzerland]. Würzburg: Ergon.

Monnot, C. (Ed.). (2013). La Suisse des mosquées. Derrière le voile de l'unité musulmane [The Switzerland of mosques. Behind the veil of Muslim unity]. Geneva: Labor et fides.

Ramji, R. (2008). Creating a genuine Islam: Second generation Muslims growing up in Canada. Canadian Diversity, 6(2), 104-109.

Schlieter, J., Kind, M., \& Lauer, T. (Eds.). (2014). Die zweite Generation der Tibeter in der Schweiz: Identitätsaushandlungen und Formen buddhistischer Religion [The second generation of Tibetans in Switzerland: Identity negotiations and types of Buddhist religion]. Zurich: Seismo.

Sedgwick, M. (Ed.). (2015). Making European Muslims. Religious socialization among young Muslims in Scandinavia and Western Europe. New York, NY: Routledge.

Stolz, J., Könemann, J., Schneuwly-Perduie, M., Engelberger, T., \& Krüggeler, M. (2014). Religion und Spiritualität in der Ich-Gesellschaft. Vier Gestalten des (Un)-Glaubens [(Un-)believing in modern society. Religion, spirituality, and religious-secular competition]. Zurich: TVZ.

Taylor, C. (1994). Multiculturalism. Examining the politics of recognition. Princeton, NJ: Princeton Univer- sity Press.

Thanissaro, N., Phra. (2014). Almost a proper Buddhist: The post-secular complexity of Heritage Buddhist teen identity in Britain. Journal of Global Buddhism, 15, 1-14.

Todd, N. R., \& Rufa, A. K. (2013). Social justice and religious participation: A qualitative investigation of Christian perspectives. American Journal of Community Psychology, 51(3/4), 315-331. https://doi.org/ 10.1007/s10464-012-9552-4

Tunger-Zanetti, A., \& Endres, J. (2019). Scouts in rough terrain. Collective strategies of Muslim youth in Switzerland for coping with exclusion. In T. Abbas \& S. Hamid (Eds.), Political Muslims. Understanding youth resistance in a global context (pp. 125-146). Syracuse, NY: Syracuse University Press.

Tunger-Zanetti, A., Martens, S., \& Endres, J. (2019). Der Tradition verbunden und doch selbständig. Muslimische Jugendliche und junge Erwachsene in der Schweiz auf der Suche nach religiöser Orientierung [Connected to tradition and yet independent. Muslim teenagers and young adults in Switzerland in search of religious orientation]. In $\mathrm{K}$. Limacher, $\mathrm{A}$. Mattes, \& C. Novak (Eds.), Prayer, pop and politics. Researching religious youth in migration society ( $\mathrm{pp}$. 179-205). Vienna: Vienna University Press.

Tunger-Zanetti, A., \& Schneuwly-Purdie, M. (2019). Switzerland. In O. Scharbrodt, S. Akgönül, A. Alibašić, J. Nielsen, \& E. Račius (Eds.), Yearbook of Muslims in Europe (Vol. 11, pp. 614-630). Leiden: Brill.

van den Brink, B., \& Owen, D. (2007). Recognition and power: Axel Honneth and the tradition of critical social theory. Cambridge: Cambridge University Press.

Voas, D., \& Fleischmann, F. (2012). Islam moves West: Religious change in the first and second generations. Annual Review of Sociology, 38, 525-545.

Weigelt, F. A. (2013). Die vietnamesisch-buddhistische Diaspora in der Schweiz. Über Organisationsstrukturen und Dynamiken buddhistischer Praxis [The Vietnamese Buddhist diaspora in Switzerland: On organizational structures and dynamics of Buddhist practice]. Hamburg: Dr. Kovac.

Wray-Lake, L., Metzger, A., \& Syvertsen, A. (2016). Testing multidimensional models of youth civic engagement: Model comparisons, measurement invariance, and age differences. Applied Developmental Science, 21(4). https://doi.org/10.1080/10888691. 2016.1205495

Zehnder Grob, S. (2013). Jugendliche in der Deutschschweiz und ihre Religiosität [Young people in German-speaking Switzerland and their religiousness]. In C. Käppler \& C. Morgenthaler (Eds.), Werteorientierung, Religiosität, Identitätsbildung und die psychische Gesundheit Jugendlicher [Value orientation, religiosity, identity building and the mental health of young people] (pp. 52-79). Stuttgart: Kohlhammer. 


\section{About the Authors}

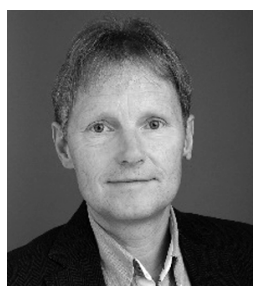

Martin Baumann is Professor and Chair at the Department for the Study of Religions at the University of Lucerne, Switzerland. He obtained his PhD with a thesis on Buddhist communities in Germany in 1993 and received his habilitation graduation with a post-doctoral thesis on Hindu tradition in diasporic Trinidad in 1999. His research interests focus on migration and religion, religious pluralism and public space, diaspora studies as well as Islam in Switzerland and Buddhist and Hindu traditions in the West.

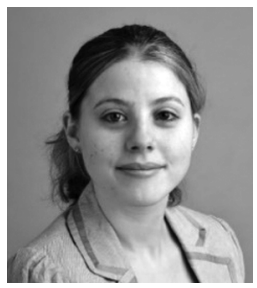

Rebekka Christine Khaliefi is a PhD candidate at the Department for the Study of Religions at the University of Lucerne, Switzerland. She has a background in Sociology and Philosophy. In her PhD project, she studies the Buddhist religion of young adults with Vietnamese roots in Switzerland and Germany. In her research, she draws on qualitative and ethnographic methods such as biographical interviews and participant observations. 